International Journal of Business Management and Economic Review

Vol. 4, No. 04; 2021

ISSN: 2581-4664

\title{
THE EFFECT OF ORGANIZATIONAL CLIMATE AND ORGANIZATIONAL JUSTICE ON WORK MOTIVATION AND ITS IMPACT ON EMPLOYEE PERFORMANCE: STUDY ON COMPANIES LISTED IN THE PIDIE JAYA CHAMBER OF COMMERCE AND INDUSTRY
}

\author{
Muhammad Ridha, Mukhlis and Said Musnadi \\ Management Department, Universitas Syiah Kuala, Indonesia \\ http://doi.org/10.35409/IJBMER.2021.3294
}

\begin{abstract}
This study aims to examine the effect of organizational climate and organizational justice on work motivation and its impact on employee performance in companies listed in the Pidie Jaya Chamber of Commerce and Industry. The population in this study was 385 employees at the companies listed in the Pidie Jaya Chamber of Commerce and Industry. This study established Stratified Proportional Random Sampling as a method and provided as many as 132 respondents as a sample. The research model was analyzed using SEM applications with the help of the Amos program. The results of the descriptive hypothesis test show that the variables of organizational climate, organizational justice, work motivation, and employee performance at companies listed in the Pidie JayaChamber of Commerce and Industry are already in good condition. The results of direct hypothesis testing show that organizational climate affects work motivation (H2), organizational justice affects work motivation (H3), organizational climate affects employee performance (H4), organizational justice affects employee performance (H5), and work motivation affects employee performance (H6). The results of indirect hypothesis testing (H7) prove that work motivation mediates (partial mediation) the influence of organizational climate on employee performance and indirect hypothesis testing (H8) also proves that work motivation mediates (partial mediation) the effect of organizational justice on employee performance. Employee persistence and creativity become the strongest predictor indicators and the highest value in the model, which is an indicator of employee performance variables. While ability is an indicator that has the lowest value in the model and must be improved, the indicator lies in the work motivation variable. Researchers recommend conducting further testing to be able to improve employee performance and work motivation by using job satisfaction, expertise, leadership, personality, and knowledge sharing variables.
\end{abstract}

Keyword: Organizational Climate, Organizational Justice, Job Satisfaction, Employee Performance.

\section{INTRODUCTION}

Covid-19, causing a weakening of the Indonesian economy in various sectors. Based on a report from the Central Statistics Agency (BPS), it is known that Indonesia's economic growth in the second quarter of 2020 fell considerably when compared to the same period in 2019, which fell by $5.02 \%$. Many entrepreneurs have started to implement a work from home (WFH) system as a form 


\section{International Journal of Business Management and Economic Review}

Vol. 4, No. 04; 2021

ISSN: 2581-4664

of social distancing appeal to prevent the spread of the Corona Virus. Not running smoothly the national economic activity automatically causes business actors to make efficiency and reallocate the work of their employees to reduce losses.

Social distancing also causes employee work productivity to drop dramatically. This is what causes the assessment of employee performance to be very strict. Employees are required to have excellent, creative, and innovative performance in order to achieve organizational goals in today's conditions. Employees are also required to know and understand in detail about the long-term business plan or the company's operations and to be aware of it during this period. Every entrepreneur is required to have creativity in increasing the added value to their business products for the continuity of the business they do. This pandemic condition encourages organizational leaders both profit and non-profit organizations to continue to maintain and encourage their employees to continue to show their performance.

The same thing also applies to companies listed in the Chamber of Commerce and Industryof Pidie Jaya (one of the districts in Indonesia) where employees are always required to work well, quality, professional, and satisfactorily so as to ensure the continuity of the organization and the employees themselves. In today's pandemic conditions, it requires every employee to be able to perform far more optimally and have high innovation and creativity so that the sustainability of the company where they work can still be maintained. This is due to the current pandemic conditions which have made the economy continue to decline, requiring every company to think extra about the steps that must be taken to maintain its business. With employees who are able to maximize their performance and have high innovation and creativity, they will be able to maintain the company's performance. The same applies to companies listed in the Pidie Jaya Chamber of Commerce and Industry.

Company performance measurement is designed to assess how activities improve performance and the final results are achieved. Theoretically, many things affect organizational performance. Among these factors that affect performance in the scope of public services include work motivation, ability, organizational climate, organizational justice, work environment, work discipline, leadership and personality(Wahyuni, Idris, \& Noor, 2013). The theory of motivation states that in every human being there is a hierarchy of five needs, namely physiological, security, social, respect, and self-actualization. This is what encourages humans to improve and improve their performance. In addition, many previous researchers have proven that motivation has a positive impact on employee performance. Where when employees have the high motivation it will directly improve their performance.

However, many organizations only demand that employees work professionally, but they do not pay attention to fairness to their employees. The result of this injustice can cause employees to act against the organization, lack commitment, not feeling satisfaction at work, and decreasing performance so that the organization does not run properly. In every company, justice is often very difficult to achieve, especially if it is judged from the perspective of every employee in the company/organization.

Management has basically tried to create a system in terms of HR management so that every employee can get the fairest information, treatment, assessment, compensation, etc. according to the performance of each employee. However, no matter how good the developed system is, dissatisfaction often arises for employees so that a sense of justice in the organization is very difficult to materialize. Likewise, companies listed in the Pidie Jaya Chamber of 


\section{International Journal of Business Management and Economic Review}

Vol. 4, No. 04; 2021

ISSN: 2581-4664

Commerce and Industry with a fairly complex HR management system also experienced the same thing. Employees feel that their income and payment benefits have not been felt to fulfill a sense of justice, because their assessment is based on attendance only, they do not see the performance or contribution of employees. Employees whose attendance is full but not working optimally or in other words, a lot of work is piling up and is delayed but gets the same work performance benefits as employees with full attendance levels with good performance who make a clear and tangible contribution to the organization.

Another thing that needs to be considered in an effort to increase work motivation and employee performance is organizational climate. The organizational climate in a company is different from other companies so that in order to achieve good employee performance, every leader in these companies must be able to create a conducive organizational climate. Organizational climate change can have a strong impact, where a better organizational climate change leads to an increase in the ability of its employees so that they can work as good teamwork as well. Organizations that are able to provide a climate that is perceived positively by employees will lead to behaviors that can support performance.

Based on the various explanations and phenomena mentioned above, the authors are interested in conducting comprehensive research with the title: The Effect of Organizational Climate and Organizational Justice on Work Motivation and its impact on Employee Performance on companies listed in the Pidie Jaya Chamber of Commerce and Industry. This research is based on several previous studies both domestic and foreign as carried out(Mulia, Adam, \& Kesuma, 2019), (Basri \& Kadir, 2019), (Purwantoro \& Bagyo, 2019), (Haryono, Ambarwati, \& Saad, 2019), (Bagyo \& Ratnasari, 2019)and(Sunarsih \& Helmiatin, 2017).Based on the phenomena that occur, it is not following the theory of causality that should be. This research model is a combination of the previous models which are integrated based on facts that occur in the field.This research also aims to look at the condition of the variables associated with the causality hypothesis. Then the $1^{\text {st }}$ Hypothesis (desctiptive) is :

H1: Organizational Climate, Organizational Justice, Work Motivation and Employee Performance in companies listed in the Pidie Jaya Chamber of Commerce and Industry are already good.

Furthermore, in building a construct for the causality hypothesis, it is described in the literature review section.

\section{LITERATURE REVIEW}

\section{The Role of Organizational Climate on Work Motivation}

Every organization or company has its way of doing business. Therefore, every organization must have a different climate from other organizations. Every organization tends to retain more people who follow the prevailing climate in the organization so that to some extent the pattern can last a long time (Basri \& Kadir, 2019). According to(Kurniasari \& Halim, 2013)stated that the existence of a good climate in an organization will be able to generate and increase work motivation. Employees who are in an organizational environment that has a good and conducive climate will be able to increase/create their initiatives and will be more loyal to their work.

Much research has been done regarding the relationship between organizational climate and work motivation. This is evident from the research conducted(Saputri, 2019),(Singh, 


\section{International Journal of Business Management and Economic Review}

Vol. 4, No. 04; 2021

ISSN: 2581-4664

Chauhan, Agrawal, Kapoor, \& Uttrakhand, 2011)stated that organizational climate has a positive influence on employee motivation. Therefore, it is important for every business actor to always pay attention to and create a conducive organizational climate in their business environment because this directly has a good impact on the work motivation of their employees. This is in line with the research conducted by(Bhaesajsanguan, 2010)who examined the relationship between organizational climate, work motivation, and organizational commitment by examining the behavior of Thai technicians in the private sector of Thai telecommunications. The results of his research prove that technician behavior depends on the climate of the organization so that it is positively related to technician work motivation.

H2: Organizational climate affects work motivation in companies listed in the Pidie Jaya Chamber of Commerce and Industry

\section{The Role of Organizational Justice on Work Motivation}

Organizational justice is one of the concepts in an organization that has developed very rapidly in recent years. According to(Parker \& Kohlmeyer, 2006)Organizational justice is the perception of organizational members about the conditions of justice they receive in the organization, in particular about the sense of justice associated with the ability of the organization to reward its members such as salaries and promotions. According to(Griffin \& Moorhead, 2013)the theory of justice motivation is based on the relatively simple premise that everyone wants to be treated fairly in the organization.(Kreitner \& Kinicki, 2013)explained that organizational justice reflects the acceptance of an employee that they are treated fairly at work.

(Hwei \& Santosa, 2012)explained that the assessment of organizational justice has an impact on employee attitudes and reactions. When employees feel that they are treated fairly, it will directly increase work motivation in achieving organizational goals. This is also supported by the results of research conducted by(Wiwiek \& Sondakh, 2015)which argued that Distributive and Interactional Justice has a positive and significant effect on Employee Motivation. The same thing is also proven by the results of research conducted by(Celik \& Sariturk, 2012), (Mada, Sintaasih, \& Subudi, 2017), and (Baba \& Ghazali, 2017) that found organizational justice has a positive and significant effect on work motivation, the results of this research concluded that with justice in an organization it can increase the work motivation of employees in the organization.

H3: Organizational justice affects work motivation in companies listed in the Pidie Jaya Chamber of Commerce and Industry

\section{The Role of Organizational Climate on Employee Performance}

(Hilmi \& Adam, 2015)mentioned performance as a record of the results obtained from job functions or activities during a certain period. Meanwhile(Afriza, Yunus, \& Musnadi, 2015)mentioned employee performance as the success that individuals can achieve in doing their job in an organization or company that can increase productivity in the form of actual employee performance compared to the expected performance of employees. Employee performance can be influenced by many factors, one of which is organizational climate. This is evidenced by the results of research conducted by(Hasanuddin, Nasir, \& Ridwan, 2019), (Basri \& Kadir, 2019), (Purwantoro \& Bagyo, 2019), (Haryono et al., 2019), (Bagyo \& Ratnasari, 2019), (Raja, Madhavi, \& Sankar, 2019), and(Syahrum, Brahmasari, \& Nugroho, 2016)where the 


\section{International Journal of Business Management and Economic Review}

Vol. 4, No. 04; 2021

ISSN: 2581-4664

organizational climate has a positive effect on employee performance which means that if the organizational climate is improved employee performance will also increase.

An organization is a group of people who gather together around the technology used to convert environmental inputs into marketable goods and services. So someone who has high performance towards the organization will have identification, sincerity, and loyalty with positive affection for the organization. In his book(Sunyoto, 2012)stated that organizational climate is a set of perceptions and feelings of various workers that can change from one worker to another and from time to time. In addition to carrying out work behavior towards the goals and desires of the organization to remain in the organization in the long term. In his research(Mahendra \& Subudi, 2019)found that organizational climate has a positive effect on employee performance. Thus, a positive organizational work climate that is shown in the form of good working conditions, harmonious relationships with colleagues and superiors, adequate work facilities, and a sense of meaning and comfort in the organization makes it easier for employees to involve themselves in organizational activities.

H4: Organizational climate affects employee performance in companies listed in the Pidie Jaya Chamber of Commerce and Industry

\section{The Role of Organizational Justice on Employee Performance}

Increased justice in the organization will provide improved employee performance. According to(Moorman, 1991)in(Meshkati, Eskandari, \& Mostahfezian, 2014)Organizational fairness is concerned with how employees determine whether they have been treated fairly in their work and how this determination affects other job-related variables. In organizational life, aspects of organizational justice are very important, because justice in the organization will make the organizational environment very conducive so that the desired output from employees will be achieved(Kristanto, 2015).

Organizational justice affects employee performance. Employees who feel treated fairly by the organization will improve performance. This is following research from(Swalhi, Zgoulli, \& Hofaidhllaoui, 2017), Where the results of these studies state that directly organizational justice both as a whole and dimensionally has a positive influence in improving employee performance. The results of other research conducted by(Moazzezi, Sattari, \& Bablan, 2014), (Mehmood \& Ahmad, 2016), and(Krishnan, Koe, Ahmad, \& Yunus, 2018)also found that employee performance is strongly influenced by organizational fairness where the results of the research conclude that with justice in an organization it can improve the performance of employees in the organization.

H5:Organizational Justice affects the performance of employees in companies listed in the Pidie Jaya Chamber of Commerce and Industry

\section{The Role of Work Motivation on Employee Performance}

(Robbins \& Judge, 2014)stated that motivation is a process that explains the intensity, persistence, and direction of an individual to achieve his goals. Motivation is an important determinant of individual achievement in addition to past skills, abilities, and experiences(Fachreza, Musnadi, \& Shabri, 2018).In work, motivation is one of the important factors an employee must have for work. Because directly, the motivation that an employee has will have a positive effect on the work he does(Robbins \& Judge, 2017). Therefore, it is 
Vol. 4, No. 04; 2021

ISSN: 2581-4664

very important for every company leader to always motivate their employees to achieve the goals of the organization. This is in line with the results of research conducted by (Azar \& Shafighi, 2013), (Shahzadi, Javed, Pirzada, Nasreen, \& Khanam, 2014), and(Gachengo \& Wekesa, 2017)found that work motivation has a positive and significant effect on employee performance, the results of these studies conclude that with the high work motivation possessed by an employee, it can improve the employee's performance.

H6: Work motivation affects employee performance in companies listed in the Pidie Jaya Chamber of Commerce and Industry

\section{The Role of Organizational Climate on Employee Performance Through Work Motivation}

Organizational climate has a positive relationship with employee performance through work motivation. This concurs with research(Ariyani, 2012)which stated that the main contribution of this study relates to the results of the pathway model which shows that work motivation not only has a direct relationship with organizational climate and employee performance but also this mediates the relationship between organizational climate and employee performance. In addition, the results of research conducted by(Fu \& Deshpande, 2013)mentioned that the climate of care also has a significant indirect impact on employee performance through the mediating role of work motivation. Organizational climate and work motivation together have a positive impact on employee performance.

H7:Organizational climate affects employee performance in companies listed in the Pidie Jaya

Chamber of Commerce and Industrythrough work motivation

\section{The Role of Organizational Justice on Employee Performance through Work Motivation}

The results of research conducted by(Zapata-Phelan, Colquitt, Scott, \& Livingston, 2009)found that organizational justice has a positive and significant influence on employee performance indirectly through work motivation, the results of this study concluded that justice in an organization can increase the work motivation of employees in the organization which indirectly matters. it can also improve the performance of employees in the organization.

H8: Organizational Justice affects Employee Performance in companies listed in the Pidie Jaya Chamber of Commerce and Industrythrough Work Motivation

\section{Research Model and Hypotheses}

This research model will explain the relationship between each variable on the improvement of work discipline which can be described as follows : 
International Journal of Business Management and Economic Review

Vol. 4, No. 04; 2021

ISSN: 2581-4664

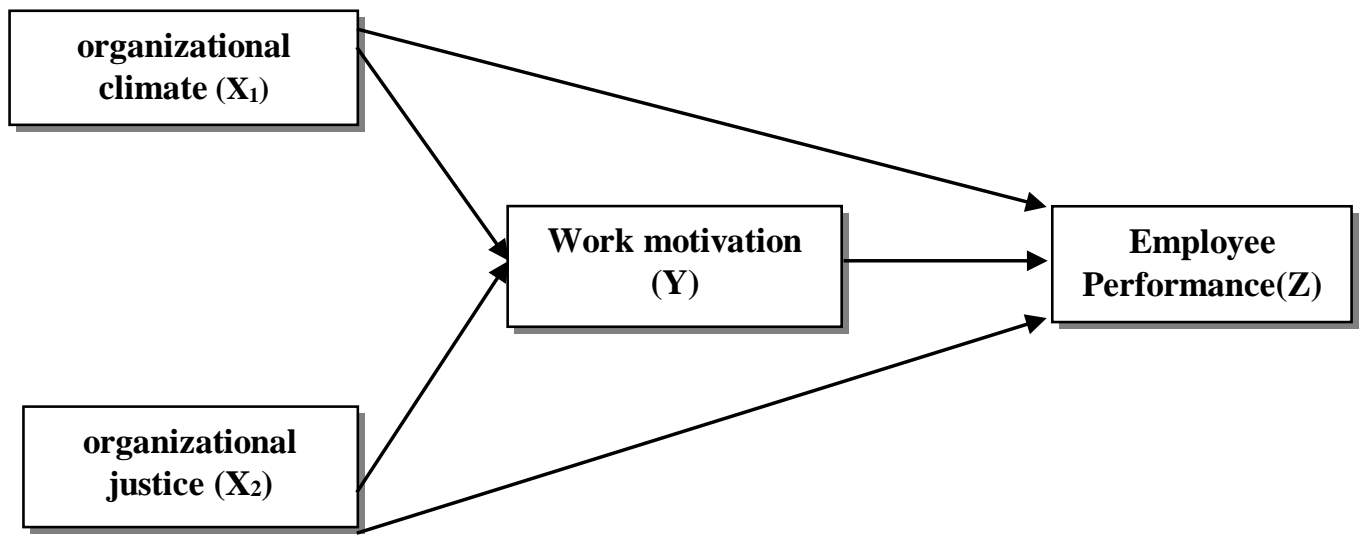

Figure 1. Research Model

Ha1: Organizational Climate, Organizational Justice, Work Motivation and Employee Performance in companies listed inthe Pidie Jaya Chamber of Commerce and Industryare already good.

Ha2: Organizational climate affects work motivation in companies listed in the Pidie Jaya Chamber of Commerce and Industry.

Ha3: Organizational Justice affects work motivation in companies listed in the Pidie Jaya Chamber of Commerce and Industry

Ha4: Organizational climate affects employee performance in companies listed in the Pidie Jaya Chamber of Commerce and Industry

Ha5: Organizational Justice affects employee performance in companies listed in the Pidie Jaya Chamber of Commerce and Industry

Ha6: Work Motivation affects Employee Performance in companies listed in the Pidie Jaya Chamber of Commerce and Industry

Ha7: Organizational climate affects the performance of employees in companies listed in the Pidie Jaya Chamber of Commerce and Industry through Work Motivation.

Ha8: Organizational Justice affects Employee Performance in companies listed in the Pidie Jaya Chamber of Commerce and Industry through Work Motivation.

\section{RESEARCH METHOD}

This research was conducted at companies listed in the Pidie Jaya Chamber of Commerce and Industry. The research object was the organizational climate, organizational justice, work motivation, and employee performance. The population was the 385 employees at companies listed in the Pidie Jaya Chamber of Commerce and Industry. This study established Stratified Proportional Random Sampling as a method of sampling based on employees at companies listed in the Pidie Jaya Chamber of Commerce and Industry. The population and sample numbers are shown in the following table. 
International Journal of Business Management and Economic Review

Vol. 4, No. 04; 2021

ISSN: 2581-4664

\section{Table 1. Research Population and Sample}

\begin{tabular}{|l|l|l|l|l|}
\hline No. & Company name & Population & $\begin{array}{r}\text { Sample } \\
\text { Proportion }\end{array}$ & Sample \\
\hline 1 & CV Antara Indo Construction Group & 15 & $\frac{15}{385} \times$ & 5 \\
\hline 2 & CV Pelita Perkasa & 18 & $\frac{18}{385} \times 132$ & 6 \\
\hline 3 & CV MeurahSetiaPersada & 16 & $\frac{16}{385} \times 132$ & 5 \\
\hline 4 & CV Surya Muda & 20 & $\frac{20}{385} \times 132$ & 7 \\
\hline 5 & CV Chitoh Jaya Mandiri & 17 & $\frac{17}{385} \times 132$ & 6 \\
\hline 6 & PT Pulo Maar Bersaudara & 53 & $\frac{53}{385} \times 132$ & 18 \\
\hline 8 & PT Antara Group & 45 & $\frac{45}{385} \times 132$ & 15 \\
\hline 9 & PT BinaPersada Jaya & 36 & $\frac{36}{385} \times 132$ & 12 \\
\hline 10 & CV Dinasty Jaya & 21 & $\frac{21}{385} \times 132$ & 7 \\
\hline 11 & CV Bunot Jaya & 16 & $\frac{16}{385} \times 132$ & 5 \\
\hline 12 & CV AneukTulot & 15 & $\frac{15}{385} \times 132$ & 5 \\
\hline 13 & CV AfdiPratama & 23 & $\frac{23}{385} \times 132$ & 8 \\
\hline 14 & PT BumiPasir Mas & 43 & $\frac{43}{385} \times 132$ & 15 \\
\hline 15 & PT AntaraZasafaBersaudara & 47 & $\frac{47}{385} \times 132$ & 16 \\
\hline Total Research Sample & 385 & & 132 \\
\hline Soura & Processed 2020$)$ & & \\
\hline
\end{tabular}

Source: Processed (2020)

Based on the table above, it is known that the number of samples in this study was 132 employees. Furthermore, the data were collected using a questionnaire method, where the list of questions asked provided answers using a Likert scale. Measurement of variables in this study used the following indicators.

1. Employee performance used indicators as disclosed by(Gomes, 2003)namely quantity, quality, creativity, cooperation, persistence, initiative, personal quality.

2. Work motivation used indicators as expressed by(Robbins \& Judge, 2014)namely the quality of work produced increases, tasks according to ability, high work initiative, work relations, and sacrifice

3. Organizational climate used indicators as stated by (Lussier, 2016), namely structure, responsibility, reward, warmth, support, organizational identity and loyalty, risk. 


\section{International Journal of Business Management and Economic Review}

Vol. 4, No. 04; 2021

ISSN: 2581-4664

4. Organizational justice used indicators as mentioned by(Meshkati et al., 2014)namely responsibility, reward, involvement, fairness, opportunity, courtesy, communication, and procedure.

To prove the hypothesis, this study used SEM statistical tools with the help of the Amos program. The reason the authors used the statistical tool was that the variables used were latent variables. With SEM, latent variables can easily be measured with one measure. There was a mediating variable, wherewith SEM this mediation problem was easier to solve and hypothesis 7 and hypothesis 8 can easily be proven. And the research sample that was used as respondents was sufficient to be analyzed using SEM.

\section{RESULT}

\section{Descriptive Hypothesis (H1)}

From the results of respondents' perceptions of each variable in this study as shown in Table 2 below.

Table 2. Recap of Respondents' Perceptions of Variables

\begin{tabular}{|c|c|c|c|c|}
\hline No & Variable & Average & Cut off & Information \\
\hline 1 & Employee Performance (Z) & 3.77 & \multirow{4}{*}{3.41} & Good \\
\hline 2 & Work Motivation(Y) & 3.80 & & Good \\
\hline 3 & Organizational Climate (X1) & 3.76 & & Good \\
\hline 4 & Organizational justice (X2) & 3.81 & & Good \\
\hline
\end{tabular}

Source: Processed data (2021)

Based on the data in table 2, shows that the respondents' perceptions of all variables in this study are already in good condition where all of these variables have obtained a mean value greater than 3.41. The next step is to do statistical testing using one sample T-test using a significant value $(\alpha=5 \%)$ and a cut-off value of 3.41. The criterion of this test is that if the significant value of the test is greater than 0.05 , the results of the descriptive hypothesis testing are that $\mathrm{H} 0$ is accepted and $\mathrm{Ha}$ is rejected. Likewise, if the test results show a significant value smaller than 0.05 , then $\mathrm{HO}$ is accepted and $\mathrm{Ha}$ is rejected. The following table shows the results of the one-sample test.

\section{Tabel3.One-Sampel T Test}

\begin{tabular}{|l|l|l|l|l|l|l|}
\hline \multirow{2}{*}{} & \multicolumn{2}{|l|}{ Test Value $=3.41$} \\
\cline { 2 - 8 } & $\mathrm{t}$ & $\mathrm{df}$ & $\begin{array}{l}\text { Sig. } \\
\text { tailed })\end{array}$ & $(2-$ & $\begin{array}{l}\text { Mean } \\
\text { Difference }\end{array}$ & \multicolumn{2}{l|}{$\begin{array}{l}\text { 95\% Confidence Interval } \\
\text { of the Difference }\end{array}$} \\
\cline { 6 - 8 } & 4.186 & 131 & .000 & .33265 & .1754 & .4899 \\
\hline $\begin{array}{l}\text { Employee } \\
\text { Performance }\end{array}$ & 4.695 & 131 & .000 & .36576 & .2116 & .5199 \\
\hline Work Motivation & 4.985 & 131 & .000 & .36818 & .2221 & .5143 \\
\hline $\begin{array}{l}\text { Organizational } \\
\text { Climate }\end{array}$ & & & & & & \\
\hline
\end{tabular}




\section{International Journal of Business Management and Economic Review}

Vol. 4, No. 04; 2021

ISSN: 2581-4664

\begin{tabular}{|l|l|l|l|l|l|l|}
\hline \hline Organizational justice & 3.936 & 131 & .000 & .31773 & .1580 & .4774 \\
\hline
\end{tabular}

Source: Processed data (2021)

The test results of a one-sample t-test with a test value $=3.41$ as shown in table 3 above, it is known that all variables show a sig value. (2-tailed) of $0.000<0.05$. With this, it can be concluded that the results of the descriptive hypothesis testing (H1) are accepted where Ha is accepted and Ho is rejected. These results can be interpreted that the organizational climate, organizational justice, work motivation, and employee performance in this study are already in good condition.

Direct Hypothesis Testing (H2,H3,H4,H5,H6)

The direct hypothesis testing is shown in the following full model SEM image

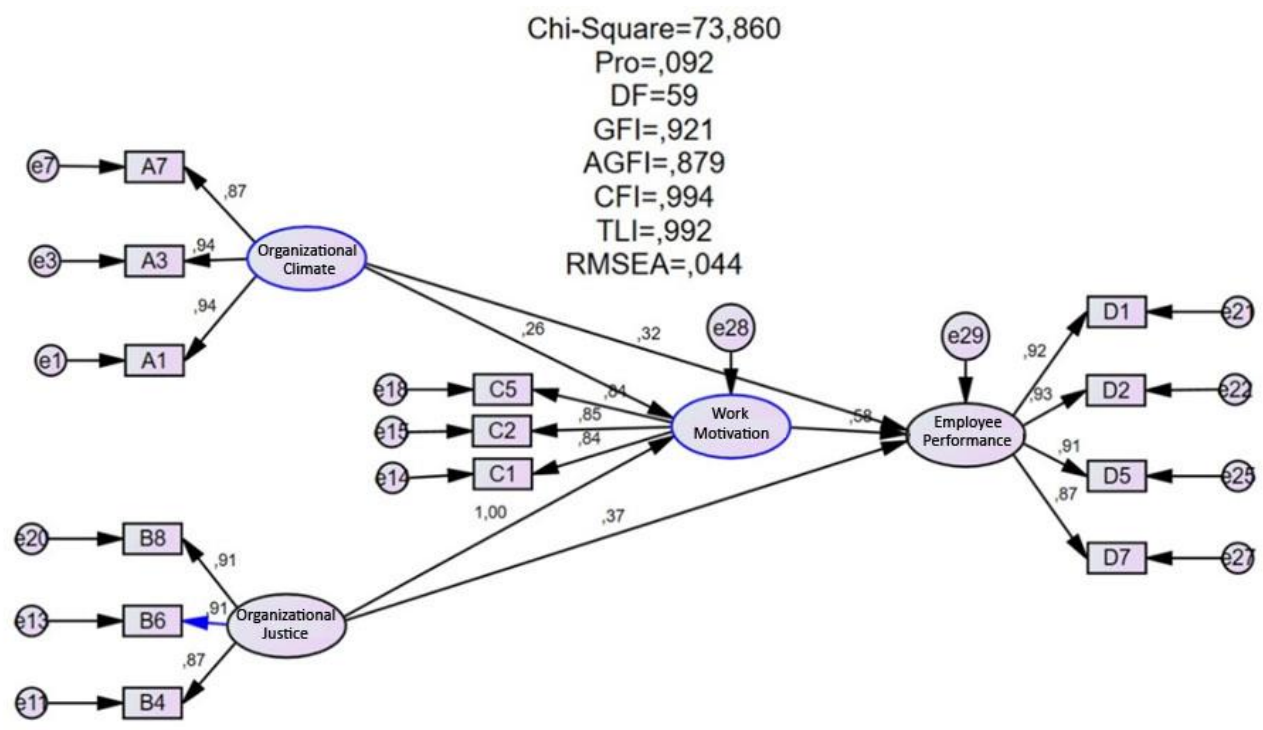

Figure 2. SEM Test Result

Based on SEM testing as shown in Figure 2 above, the following results are obtained

Table 4. Results of Direct Hypothesis Submission

\begin{tabular}{|c|c|c|c|c|c|c|c|}
\hline & \multicolumn{2}{|l|}{ Estimate } & \multirow{2}{*}{ S.E. } & \multirow{2}{*}{ C.R. } & \multirow{2}{*}{$\mathbf{P}$} \\
\hline & & & Standardized & Unstandardized & & & \\
\hline Work Motivation & $<--$ & $\begin{array}{l}\text { Orgizational } \\
\text { Climate }\end{array}$ & .265 & 174 & .025 & 7.030 & $* * *$ \\
\hline Work Motivation & $<--$ & $\begin{array}{l}\text { Organizational } \\
\text { Justice }\end{array}$ & .996 & .822 & .056 & 14.710 & **** \\
\hline $\begin{array}{l}\text { Employee } \\
\text { Performance }\end{array}$ & $<--$ & $\begin{array}{l}\text { Orgizational } \\
\text { Climate }\end{array}$ & .324 & 206 & .029 & 7.103 & **** \\
\hline Employee & $<--$ & Work Motivation & .576 & .659 & .315 & 2.095 & .036 \\
\hline
\end{tabular}




\section{International Journal of Business Management and Economic Review}

Vol. 4, No. 04; 2021

ISSN: 2581-4664

\begin{tabular}{|c|c|c|c|c|c|c|}
\hline & & \multicolumn{2}{|c|}{ Estimate } & \multirow[t]{2}{*}{ S.E. } & \multirow[t]{2}{*}{ C.R. } & \multirow[t]{2}{*}{$\mathbf{P}$} \\
\hline Performance & & & & & & \\
\hline $\begin{array}{l}\text { Employee } \\
\text { Performance }\end{array}$ & $\begin{array}{ll}<--- & \begin{array}{l}\text { Organizational } \\
\text { Justice }\end{array}\end{array}$ & .373 & .391 & .064 & 6.109 & $* * *$ \\
\hline
\end{tabular}

Source: Primary data, 2021 (processed)

Based on the results of the analysis of direct hypothesis testing in table 5 above, the statistical equations can be formulated as follows:

Work Motivation $\quad=0.265$ Organizational Climate +0.996 Organizational Justice

Employee Performance $=0.324$ Organizational Climate +0.373 Organizational Justice +0.576

Work Motivation

By looking at the test results in table 5 above, the results of direct hypothesis testing can be explained as follows:

Testing The RoleOf Organizational Climate On Employee Motivation In Companies listed in The Pidie Jaya Chamber of Commerce and Industry (H2)

The results of testing the direct hypothesis of the effect of organizational climate on employee motivation at companies listed in the Pidie Jaya Chamber of Commerce and Industry obtained a critical ratio (C.R) of 7.030, greater than the cut-off value of 1.96. The significance or probability value of 0,000 is smaller than 0.05 . The amount of direct influence of organizational climate on work motivation is 0.265 or $26.5 \%$. Thus, hypothesis testing (H2) is accepted, which results in $\mathrm{Ha} 2$ accepted and $\mathrm{H} 02$ rejected, which means that organizational climate affects employee motivation at companies listed in the Pidie Jaya Chamber of Commerce and Industry. The results of this study are in line with the results of research conducted by(Saputri, 2019), (Sari, 2018), (Yantu, 2018), (Madhukar \& Sharma, 2017), (Gaunya, 2016)and(Rusu \& Avasilcai, 2014)where the results of their research also showed that organizational climate affects employee motivation.

From these results, it can be seen that the better the organizational climate, the more employee motivation will be in the Companies listed in The Pidie Jaya Chamber of Commerce and Industry. This shows that every leader in these companies must always be able to maintain and improve the organizational climate within the company to increase employee motivation. Every company has its way of doing business. Therefore, the organizational climate created in a company must also be different. It is important for every company, especially those listedin the Pidie Jaya Chamber of Commerce and Industry, to continue to create a conducive organizational climate. Based on the opinions given by employee respondents who work for companies listed in the Pidie Jaya Chamber of Commerce and Industry, several things must be improved in terms of organizational climate to improve work motivation. These matters are providing support to each employee by considering both financial and social aspects, overcoming and taking over job risks generated by each employee, and company leaders who can increase the satisfaction that employees have with the company. By fixing and enhancing these things, it is hoped that the organizational climate will be able to further foster motivation for its employees.

Testing the Role of Organizational Justice on Work Motivation of Employees in Companies listed in The Pidie Jaya Chamber of Commerce and Industry (H3) 


\section{International Journal of Business Management and Economic Review}

Vol. 4, No. 04; 2021

ISSN: 2581-4664

Based on table 5 above, shows the results of testing the direct hypothesis of the effect of organizational justice on employee work motivation at companies listed in the Pidie Jaya Chamber of Commerce and Industry, the critical ratio (C.R) value of 14.710 is greater than the cut-off value of 1.96. The significance or probability value of 0,000 is smaller than 0.05 . The amount of direct influence of organizational justice on work motivation is 0.996 or $99.6 \%$. Thus, hypothesis testing (H3) is accepted, which results in $\mathrm{Ha} 3$ accepted and $\mathrm{H} 03$ rejected, which means that organizational justice affects employee motivation at companies listed in the Pidie Jaya Chamber of Commerce and Industry. The results of this study are in line with the results of research conducted by(Baba \& Ghazali, 2017), (Mada et al., 2017), (Ghazi \& Jalali, 2017), (Wiwiek \& Sondakh, 2015)where their research also proved that organizational justice affects employee motivation.

From the results of research and literature studies that have been done, it proves that the higher the level of fairness in an organization, the higher the level of work motivation possessed by employees. When employees feel that they are treated fairly, it will directly increase work motivation in achieving organizational goals. For this reason, every leader of each company must always pay attention to and assess the level of organizational justice that has been applied in their respective organizations. Based on the opinions given by employee respondents who work for companies listed in the Pidie Jaya Chamber of Commerce and Industry, there are several things that must be improved in terms of organizational justice to increase work motivation. These things are that the level of burden and responsibility imposed on employees must be evenly distributed and following the capabilities of each employee, the application of regulations / fair decision making, involving employees in decision making and giving employees the right to supervise the application of regulations in the environment. the company, as well as the communication procedures carried out by the leadership to its employees can be done properly / in appropriate words. These things must be the full attention of every company leader incompanies listed in the Pidie Jaya Chamber of Commerce and Industry so that the improvement is expected to further increase the motivation of their employees to work.

Testing the Role of Organizational Climate on Employee Performance in Companies listed in The Pidie Jaya Chamber of Commerce and Industry (H4)

The results of testing the direct hypothesis of the influence of organizational climate on employee performance at companies listed in the Pidie Jaya Chamber of Commerce and Industry obtained a critical ratio (C.R) value of 7.103, greater than the cut-off value of 1.96 . The significance or probability value of 0,000 is smaller than 0.05 . The amount of direct influence of organizational climate on employee performance is 0.324 or $32.4 \%$. Thus hypothesis testing (H4) is accepted, which results in $\mathrm{Ha} 4$ accepted and $\mathrm{H} 04$ rejected, which results indicate that organizational climate affects employee performance at companies listed in the Pidie Jaya Chamber of Commerce and Industry. The results of this study further strengthen the results of previous research conducted by(Hasanuddin et al., 2019), (Basri \& Kadir, 2019), (Purwantoro \& Bagyo, 2019), (Haryono et al., 2019), (Bagyo \& Ratnasari, 2019), (Raja et al., 2019), (Diputra, Agung, \& Kepramareni, 2018)and(Sunarsih \& Helmiatin, 2017)where the results of their research also showed that organizational climate has a significant influence on employee performance.

The results of this study indicate that the better the organizational climate of a company, 


\section{International Journal of Business Management and Economic Review}

Vol. 4, No. 04; 2021

ISSN: 2581-4664

the better the employee's performance will be in order to achieve the goals of each company. Organizational climate change has a strong influence on performance. Based on the opinions given by employee respondents who work for companies listed in the Pidie Jaya Chamber of Commerce and Industry, several things need to be improved in terms of organizational climate to improve employee performance, namely overcoming risks, organizational support, more regulations, and procedures. flexible, and strict and fair supervision of all employees. With the improvements to these indicators, it is hoped that the organizational climate will be more conducive so that employees can produce maximum performance with much better / improved results.

Testing the Role of Organizational Justice on Employee Performance in Companies listed in The Pidie Jaya Chamber of Commerce and Industry (H5)

The results of testing the direct hypothesis of the effect of organizational justice on employee performance at companies listed in the Pidie Jaya Chamber of Commerce and Industry obtained a critical ratio (C.R) value of 6.109 , greater than the cut-off value of 1.96 . The significance or probability value of 0,000 is smaller than 0.05 . The amount of direct influence of organizational justice on employee performance is 0.373 or $37.3 \%$. Thus, hypothesis testing (H5) is accepted, which results in $\mathrm{Ha} 5$ accepted and $\mathrm{H} 05$ rejected, which means that organizational justice affects employee performance in companies listed in the Pidie Jaya Chamber of Commerce and Industry. The results of this study are in line with the results of research conducted by(Paracha, Malik, Azeem, \& Yasmin, 2020), (Haryono et al., 2019), (Pecino et al., 2019), (Purwantoro \& Bagyo, 2019), (Bagyo \& Ratnasari, 2019), (Iqbal, Rehan, Fatima, $\&$ Nawab, 2017)where the results of their research proved that organizational justice has a positive and significant effect on employee performance.

Based on the results of research and literature studies that have been carried out, it is evident that the better the justice in an organization, the better the employee's performance will be. Based on the opinions given by employee respondents who work for companies listed in the Pidie Jaya Chamber of Commerce and Industry, several things must be improved in terms of organizational justice for employee performance, namely giving equal responsibility according to the abilities possessed by each. Employees, appropriate rewards and bonuses to employees who have excellent performance, implementing procedures within the company, as well as providing opportunities to all employees, especially in their efforts to develop themselves. With the improvements to these things, it is hoped that it will create better organizational justice so that with a good level of justice felt by employees will be able to give birth to better employee performance as well.

Testing the Role of Work Motivation on Employee Performance in Companies listed in The Pidie Jaya Chamber of Commerce and Industry (H6)

The results of testing the direct hypothesis of the effect of work motivation on employee performance at companies listed in the Pidie Jaya Chamber of Commerce and Industry obtained a critical ratio (C.R) of 2.095, greater than the cut-off value of 1.96. The significance or probability value of 0.036 is smaller than 0.05 . The amount of direct influence of work motivation on employee performance is 0.576 or $57.6 \%$. Thus, hypothesis testing (H6) is accepted, which results in Ha6 accepted and H06 rejected, which means that work motivation 


\section{International Journal of Business Management and Economic Review}

Vol. 4, No. 04; 2021

ISSN: 2581-4664

affects employee performance in companies listed in the Pidie Jaya Chamber of Commerce and Industry. The results of this study are in line with the results of research conducted by(Ananda, Nasir, \& Musnadi, 2019), (Basri \& Kadir, 2019), (Purwantoro \& Bagyo, 2019), (Diana, Tabrani, \& Chan, 2019), (Bagyo \& Ratnasari, 2019), (Mulia et al., 2019), (Hanum, Musnadi, \& Harmen, 2019)and(Sunarsih \& Helmiatin, 2017)where the results of their research also proved that work motivation has a positive and significant effect on employee performance.

The results of this research also show that the better the level of work motivation possessed by each employee, the better the performance produced by each employee. In the context of work, motivation is an important factor in encouraging an employee to work. There are three key elements in motivation, namely effort, organizational goals, and needs. To be able to continue to increase the work motivation of its employees, every leader in each company, especially those listedin the Pidie Jaya Chamber of Commerce and Industry, must always have these three elements.

\section{Indirect Hypothesis Testing (Mediation, $\mathrm{H7}$ and H8))}

Testing TheRole of Organizational Climate on Employee Performance Through Work Motivation (H7)

To find out the mediating effect of work motivation on the relationship between organizational climate and employee performance, this study uses a Sobel test calculator with an unstandardized estimate value. The test results using the Sobel calculator are shown in the following figure

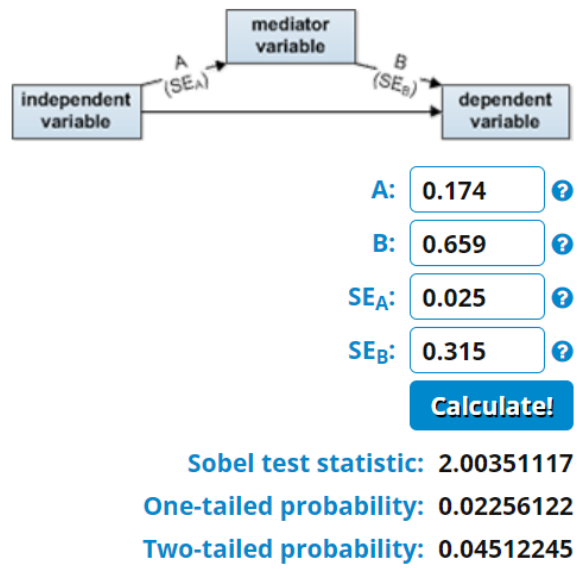

Figure 3.Sobel Test Result of Hypothesis 7

From the results of hypothesis testing, the indirect effect of organizational climate on employee performance through work motivation shows a statistical test of 2.003>1.96 and a pvalue of $0.045<0.05$. These results indicate that hypothesis testing 7 is accepted where $\mathrm{Ha} 7$ is accepted and $\mathrm{H} 07$ is rejected. So with this proves that work motivation mediates the influence of organizational climate on employee performance in companies listed in the Pidie Jaya Chamber of Commerce and Industry. Based on the results of the significance calculation for line $\mathrm{C}$ 'using the Sobel test, it can be illustrated visually for all paths A, B, C, and C' to test the effect of the influence of organizational climate on employee performance in companies listed in the Pidie JayaChamber of Commerce and Industry through work innovation as shown in the following 
International Journal of Business Management and Economic Review

Vol. 4, No. 04; 2021

ISSN: 2581-4664

picture.

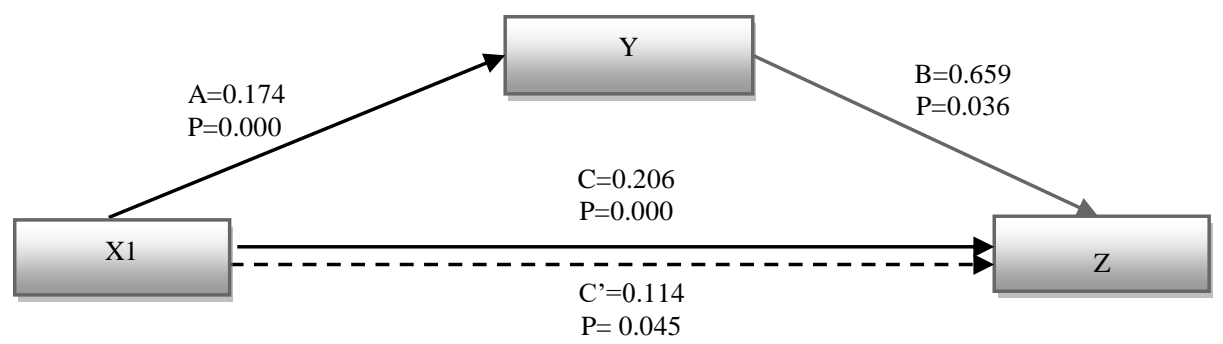

Figure 4. Mediation Effect of Hypothesis 7

Figure 4 above can be explained that the organizational climate variable affects work motivation by explaining that the path coefficient $A$ has a value of $\beta=0.174$ and a value of $p=$ $0.000<0.05$. Path $B$ has a value of $\beta=0.659$ and $p$-value $=0.036<0.05$. From the value of path $\mathrm{A}$ and $\mathrm{B}$, it can be concluded that it is significant, while path $\mathrm{C}$ has a value of $\beta=0.206$ and a value of $p=0.000<0.05$ and $C$ 'has a value of $\beta=0.114(0.174 \times 0.659=0.114)$ and a $p$-value $=$ $0.045<0,05$. This value indicates that pathways A, B, C, and C 'are significant or often referred to as partial mediation. The magnitude of the mediating role of work motivation on the influence of organizational climate on employee performance is 0.114 or $11.4 \%$. The results of this study are the same as the results of research conducted by(Diputra et al., 2018)

Testing The Role of Organizational Justice on Employee Performance Through Work Motivation (H8)

The results of testing hypothesis 8 are the effect of organizational justice on employee performance through work motivation as shown in the figure below.

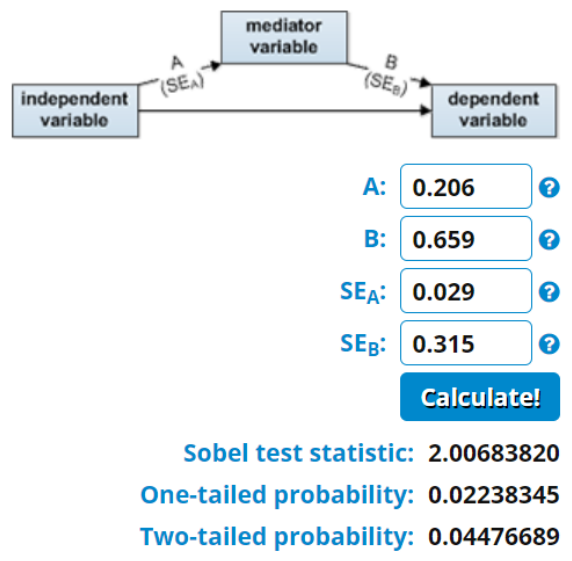

Figure 5.Sobel Test Result of Hypothesis 8

From the results of hypothesis testing, the indirect effect of organizational justice on employee performance through work motivation shows a statistical test of 2.006> 1.96 and a pvalue of $0.044<0.05$. These results indicate that hypothesis testing 8 is accepted where $\mathrm{Ha} 8$ is accepted and $\mathrm{H} 08$ is rejected. So with this proves that work motivation mediates the effect of 
Vol. 4, No. 04; 2021

ISSN: 2581-4664

organizational justice on employee performance in companies listed in the Pidie Jaya Chamber of Commerce and Industry. Based on the results of the significance calculation for line $\mathrm{C}$ 'using the Sobel test, it can be illustrated visually for all paths A, B, C, and C' to test the indirect effect of organizational justice on employee performance through work motivation as shown in the following figure.

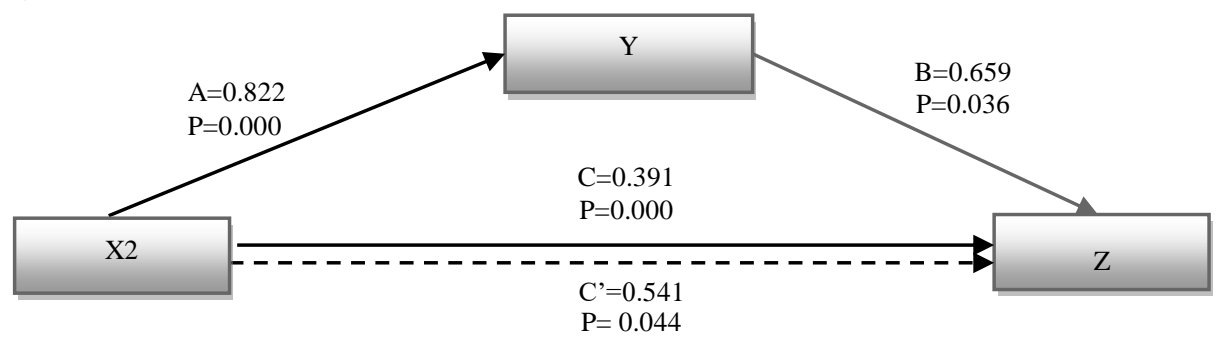

Figure 6. Mediation Effect of Hypothesis 8

Figure 6 above can be explained that the organizational climate variable affects work motivation by explaining that the path coefficient $A$ has a value of $\beta=0.174$ and a value of $p=$ $0.000<0.05$. Path $B$ has a value of $\beta=0.659$ and $p$-value $=0.036<0.05$. From the value of path $A$ and $B$ it can be concluded that it is significant, while path $C$ has a value of $\beta=0.206$ and a value of $p=0.000>0.05$ and $C$ has a value of $\beta=(0.822 \times 0.659=0.541)$ and a value of $p=$ $0.044<0,05$. This value indicates that pathways A, B, C, and C 'are significant or often referred to as partial mediation. The magnitude of the mediating role of work motivation on the effect of organizational justice on employee performance is 0.541 or $54.1 \%$. The results of this study are a novelty where there have not been any previous researchers who have researched the mediating role of work motivation on the effect of organizational justice on employee performance. The results of this study can also be a reference for future researchers.

\section{CONCLUSION}

The results of research on companies listed in the Pidie Jaya Chamber of Commerce and Industry concludes that:

1) The results of the descriptive hypothesis testing show that the variables of organizational climate, organizational justice, work motivation, and employee performance in companies listed in the Pidie Jaya Chamber of Commerce and Industry are already in good condition. This can be seen from the acquisition of the mean value of each variable that obtained a value above 3.41 and a probability value less than 0.05 .

2) The results of direct hypothesis testing show that organizational climate affects work motivation $(\mathrm{H} 2)$, organizational justice affects work motivation $(\mathrm{H} 3)$, organizational climate affects employee performance (H4), organizational justice affects employee performance (H5), and work motivation affects employee performance (H6).

3) The results of indirect hypothesis testing (H7) prove that work motivation mediates (partial mediation) the influence of organizational climate on employee performance and indirect hypothesis testing (H8) also proves that work motivation mediates (partial mediation) the effect of organizational justice on employee performance. 


\section{International Journal of Business Management and Economic Review}

Vol. 4, No. 04; 2021

ISSN: 2581-4664

These findings are in line with the research that has been done by previous researchers so that it becomes a new premise to strengthen the previous theory of causality. The novelty lies in incorporating these theories into a model for improving employee performance in companies listed in the Pidie Jaya Chamber of Commerce and Industry that can be implemented today. Further researchers are also expected to be able to further develop this tested research model by adding other variables such as job satisfaction, expertise, leadership, personality, and knowledge sharing variables.

Some things that can be recommended to the leaders of companies listed in the Pidie Jaya Chamber of Commerce and Industry are as follows.

1. In order to improve employee performance, company leaders must always pay attention to variables that can improve employee performance, especially organizational climate, organizational justice, and work motivation. The leadership of the company must establish a written policy regarding reward and punishment in order to continue to trigger and increase work motivation and employee performance.

2. Following the description of employee performance variables, company leaders must be able to further increase the persistence and creativity of their employees by providing facilities for their employees to be able to attend training / self-development ToT related to the field of work they do. With this facility, it is hoped that employees can continue to develop their determination and creativity in an effort to continuously improve their performance.

3. In the work motivation variable, it is known that the task indicator according to ability has the lowest value. For this reason, the leadership of the company must conduct a comprehensive re-evaluation of the limits of the capabilities of each employee and rearrange the provision of duties and functions for each employee according to their abilities. The ability of employees greatly determines their ability to complete their responsibilities in carrying out their work. Company leaders must also provide opportunities and facilitate their employees to be able to take part in self-development programs, be it further studies, training, ToT, workshops and so on which are related to the development of abilities for their employees.

4. In an effort to improve the organizational climate, company leaders must be able to provide full support for their employees and be able to overcome all risks generated in the field. Company leaders must also be able to further improve employee satisfaction for the company so that employees will be more loyal to work. Problems relating to providing support to employees, increasing employee satisfaction with the company, and taking over risk by the company must be made in writing. With this written rule, it is hoped that every employee can be more focused in carrying out their work.

5. Leaders must be able to create a fairer organization by providing a balanced load of responsibility for each employee in the same position. The distribution of work responsibilities must be made in writing in the form of company regulations and does not violate the prevailing laws and regulations. 
International Journal of Business Management and Economic Review

Vol. 4, No. 04; 2021

ISSN: 2581-4664

\section{REFERENCES}

Afriza, M., Yunus, M., \& Musnadi, S. (2015). Pengaruh Penempatan, Kompensasi dan Komunikasi Terhadap Motivasi Kerja Serta Dampaknya Pada Kinerja Pegawai Badan Layanan Umun Daerah Rumah Sakit Ibu dan Anak Pemerintah Aceh. Jurnal Manjemen Pascasarjana Universitas Syiah Kuala, 4(3), 189-198.

Ananda, M. R., Nasir, \& Musnadi, S. (2019). The Effect of Organizational Learning on Organizational Performance through Mediations: Study in Government Secretariat of Pidie Jaya. East African Scholars Journal of Economics, Business, and Management, 2(9), 480485.

Ariyani, E. D. (2012). Dampak Iklim Organisasi Terhadap Kepuasan Kerja (Studi pada Karyawan Tetap di Polman Bandung). Manajerial Jurnal Manajemen Dan Sistem Informasi, 11(2), 68-80. https://doi.org/https://doi.org/10.17509/manajerial.v11i2.2175

Azar, M., \& Shafighi, A. A. (2013). The Effect of Work Motivation on Employees' Job Performance (Case Study: Employees of Isfahan Islamic Revolution Housing Foundation). International Journal of Academic Research in Business and Social Sciences, 3(9), 432445. https://doi.org/10.6007/IJARBSS/v3-i9/231

Baba, A., \& Ghazali, S. B. (2017). Influence Of Organizational Justice On Motivation Of Public Sector Employees In Nigeria: An Empirical Investigation. International Journal of Management Research \& Review, 7(9), 913-925.

Bagyo, Y., \& Ratnasari, S. D. (2019). Organizational Citizenship Behavior Ability to Increase the Effect of Organizational Climate, Work Motivation and Organizational Justice on Employee Performance. Journal of Resources Development and Management, 59, $26-37$. https://doi.org/10.7176/JRDM/59-04

Basri, M., \& Kadir, A. (2019). Pengaruh Motivasi Kerja Dan Iklim Organisasi Terhadap Kinerja Pegawai Pada Lembaga Penjaminan Mutu Pendidikan Provinsi Sulawesi Tenggara. Journal Publicuho, 2(1), 1-14. https://doi.org/DOI: http://dx.doi.org/10.35817/jpu.v2i1.5854

Bhaesajsanguan, S. (2010). The Relationships among Organizational Climate, Job Satisfaction and Organizational Commitment in the Thai Telecommunication Industry. E-Leader Singapore Journal, 10, 1-15.

Celik, M., \& Sariturk, M. (2012). Organizational Justice And Motivation Relationship: The Case Of Adiyaman University. Istanbul Commerce University Journal of Social Sciences, Istanbul Commerce University, 21(1), 353-382.

Diana, T., Tabrani, M., \& Chan, S. (2019). Indirect Effects of Participative Leadership Style and Non-Financial Compensation on Employee Performance through Work Motivation. East African Scholars Journal of Economics, Business and Management, 2(7), 369-375.

Diputra, D. G. A. S., Agung, A. A. P., \& Kepramareni, P. (2018). The Influence of Leadership and Organizational Climate of Employee Performance through Motivation as a Mediation Variable. International Journal of Contemporary Research and Review, 9(8), 20986-20996. https://doi.org/10.15520/ijcrr/2018/9/08/571 


\section{International Journal of Business Management and Economic Review}

Vol. 4, No. 04; 2021

ISSN: 2581-4664

Fachreza, Musnadi, S., \& Shabri, M. (2018). Pengaruh Motivasi Kerja, Lingkungan Kerja, dan Budaya Organisasi Terhadap Kinerja Karyawan dan Dampaknya Pada Kinerja Bank Aceh Syariah Di Kota Banda Aceh. Jurnal Magister Manajemen, 2(1), 115-122.

Fu, W., \& Deshpande, S. P. (2013). The Impact of Caring Climate, Job Satisfaction, and Organizational Commitment on Job Performance of Employees in a China's Insurance Company. Journal of Business Ethics, 124(2), 339-349. https://doi.org/10.1007/s10551013-1876-y

Gachengo, V., \& Wekesa, S. (2017). Influence of motivation on employee performance: a case of national bank of Kenya. Journal of Business, Management and Social Research, 3(2), 179-185.

Gaunya, C. R. (2016). Organizational Climate as a Determinant of Job Satisfaction among Public Sector Employees in Kisii County, Kenya. Journal of Resources Development and Management, 23, 47-53.

Ghazi, M., \& Jalali, S. M. (2017). The Effects of Organizational Justice and job Motivation on Organizational Citizenship Behavior and its Impact on Taxpayers. Revista Administração Em Diálogo, 19, 1-21. Retrieved from http://www.redalyc.org/articulo.oa?id=534655933003

Gomes, F. C. (2003). Manajemen sumber daya manusia. Yogyakarta: Andi.

Griffin, R. W., \& Moorhead, G. (2013). Bachelor of Commerce Programme Organizational Organizational Behavior: Managing People and Organizations (10th ed.). Canada: Nelson Education, Ltd.

Hanum, K., Musnadi, S., \& Harmen, H. (2019). Determinant of Employee Performance : Case in Diskop UKM. Global Journal of Management and Business, 19(10-A), 6-14. Retrieved from https://journalofbusiness.org/index.php/GJMBR/article/view/2848

Haryono, S., Ambarwati, Y. I., \& Saad, M. S. M. (2019). Do organizational climate and organizational justice enhance job performance through job satisfaction? A study of Indonesian employees. Academy of Strategic Management Journal, 18(1), 1-6.

Hasanuddin, Nasir, \& Ridwan. (2019). Factors Affecting Employee Performance And Organizational Performance At PT. Bank Aceh Syariah. International Journal of Business Management and Economic Review, 2(6), 68-74. https://doi.org/http://doi.org/10.35409/IJBMER.2019.2429

Hilmi, H., \& Adam, M. (2015). The Influence of Competencies and Motivation on Employee Performance: In the Job Satisfaction Perspective. JOURNAL OF ECONOMIC SCIENCE (JECS), l(1). Retrieved from http://jurnal.uui.ac.id

Hwei, S., \& Santosa, T. E. C. (2012). Pengaruh Keadilan Prosedural dan Keadilan Distributif terhadap Komitmen Organisasi. Jurnal Dinamika Ekonomi Dan Bisnis, 9(2), 37-52. https://doi.org/https://doi.org/10.34001/jdeb.v9i2.14

Iqbal, M. Z., Rehan, M., Fatima, A., \& Nawab, S. (2017). The Impact of Organizational Justice on Employee Performance in Public Sector Organization of Pakistan. International Journal 


\section{International Journal of Business Management and Economic Review}

Vol. 4, No. 04; 2021

ISSN: 2581-4664

of Economics \& Management Sciences, 6(3), 1-6. https://doi.org/10.4172/21626359.1000431

Kreitner, R., \& Kinicki, A. J. (2013). Perilaku Organisasi Bk.2 (9th ed.). Jakarta: Salemba Empat.

Krishnan, R., Koe, W.-L., Ahmad, N. A. F. binti, \& Yunus, N. A. S. (2018). Examining the Relationship between Organizational Justice and Job Performance. International Journal of Academic Research in Business and Social Sciences, 8(3), 466-477. https://doi.org/10.6007/IJARBSS/v8-i3/3942

Kristanto, H. (2015). Keadilan Organisasional, Komitmen Organisasi dan Kinerja Karyawan. $J M K, 17(1), 86-98$.

Kurniasari, D., \& Halim, A. (2013). Pengaruh Lingkungan Kerja dan Iklim Organisasi terhadap Komitmen Organisasi Melalui Kepuasan Kerja Karyawan pada Dinas Pasar Unit Pasar Tanjung Kabupaten Jember. Jurnal Ilmu Ekonomi, 8(2), 273.

Lussier, R. (2016). Human Relations in Organizations: Applications and Skill Building (Irwin Management) (10th ed.). New York: McGraw-Hill.

Mada, I. G. N. C. W., Sintaasih, D. K., \& Subudi, M. (2017). Pengaruh Keadilan Organisasional Terhadap Motivasi Dan Kinerja Karyawan. Jurnal Forum Manajemen, 15(2), 1-18. https://doi.org/https://doi.org/10.20885/jsb.vol19.iss1.art6

Madhukar, V., \& Sharma, E. S. (2017). Impact Of Organisational Climate On Employee Motivation: A Conceptual Perspective. International Journal in Management and Social Science, 5(7), 325-336.

Mahendra, I. K., \& Subudi, M. (2019). Pengaruh Iklim Organisasi dan Sistem Reward Terhadap Kepuasan kerja dan Komitmen Organisasinal pada CV. Wiracana. E-Jurnal Ekonomi Dan Bisnis Universitas Udayana, 8(4), 395-412.

Mehmood, N., \& Ahmad, U. N. U. (2016). Organizational Justice And Employee Performance: Evidence From Higher Education Sector In Pakistan. Jurnal Kemanusiaan, 14(2), 48-56.

Meshkati, Z., Eskandari, B., \& Mostahfezian, M. (2014). The relationship between organizational justice, organizational citizenship behavior, and organizational trust: A case study of the employees of the department of youth and sports. Research in Sport Management and Psychology, 2(2), 39-44.

Moazzezi, M., Sattari, S., \& Bablan, A. Z. (2014). Relationship between Organizational Justice and Job Performance of Payamenoor University Employees in Ardabil Province. Singaporean Journal of Business Economic, and Management Studies, 2(6), 57-64.

Moorman, R. H. (1991). Relationship between organizational justice and organizational citizenship behaviors: Do fairness perceptions influence employee citizenship? Journal of Applied Psychology, 76(6), 845-855. https://doi.org/https://doi.org/10.1037/00219010.76.6.845

Mulia, T., Adam, M., \& Kesuma, T. M. (2019). How The Organizational Commitment Works 


\section{International Journal of Business Management and Economic Review}

Vol. 4, No. 04; 2021

ISSN: 2581-4664

As A Mediation Variabel? Study in Aceh Natural Resources Conservation Centre. East African Scholars Journal of Economics, Business and Management, 2(8), 416-420.

Paracha, A. T., Malik, S., Azeem, M., \& Yasmin, R. (2020). Impact of Organizational Justice on Employee Performance: Mediating Role of Emotional Intelligence: An Analysis of Public Sector Organizations of Pakistan. Journal of Managerial Sciences, XI(3), 315-334.

Parker, R. J., \& Kohlmeyer, J. M. (2006). Organizational Justice and Turnover in Public Accounting Firms: A Research Note. Accounting Organizations and Society, 30(4), 357369. https://doi.org/10.1016/j.aos.2004.05.001

Pecino, V., Mañas, M. A., Díaz-Fúnez, P. A., Aguilar-Parra, J. M., Padilla-Góngora, D., \& López-Liria, R. (2019). Organisational Climate, Role Stress, and Public Employees' Job Satisfaction. International Journal of Envirenmental Research and Public Health, 16(10), 1-12. https://doi.org/10.3390/ijerph16101792

Purwantoro, H., \& Bagyo, Y. (2019). Organizational citizenship behavior are able to improve the effect of organizational climate, work motivation and organizational justice on employee performance. Management and Economics Journal, 3(2), 88-111.

Raja, S., Madhavi, C., \& Sankar, S. (2019). Influence of Organizational Climate on Employee Performance in Manufacturing Industry. Suraj Punj Journal For Multidisciplinary Research, 9(3), 146-157.

Robbins, S. P., \& Judge, T. A. (2014). Buku Perilaku Organisasi Buku 2 (Edisi ke-1; alih bahasa D. Angelica, ed.). Salemba Empat.

Robbins, S. P., \& Judge, T. A. (2017). Essential of Organisational Behaviour (14th ed.). New Jersey: Pearson.

Rusu, G., \& Avasilcai, S. (2014). Linking human resources motivation to organizational climate. Procedia - Social and Behavioral Sciences, 124, 51-58. https://doi.org/10.1016/j.sbspro.2014.02.459

Saputri, M. (2019). Pengaruh Iklim Organisasi Terhadap Motivasi Kerja Karyawan PT. Taspen (Persero) Padang. Daya Saing Jurnal Ilmu Manajemen, 5(3), 284-289. https://doi.org/https://doi.org/10.35446/dayasaing.v5i3.411

Sari, M. (2018). Pengaruh Kompensasi, Iklim Organisasi Dan Gaya Kepemimpinan Terhadap Motivasi Kerja Serta Dampaknya Pada Kinerja Karyawan Dinas Perumahan Rakyat Dan Kawasan Pemukiman Aceh. Universitas Syiah Kuala.

Shahzadi, I., Javed, A., Pirzada, S. S., Nasreen, S., \& Khanam, F. (2014). Impact of Employee Motivation on Employee Performance. Europan Journal of Business and Management, 6(23), 159-166.

Singh, R. R., Chauhan, A. K. S., Agrawal, S., Kapoor, S., \& Uttrakhand, R. (2011). Impact Of Organisational Climate On Job Satisfaction - A Comparative Study. IJCSMS International Journal of Computer Science and Management Studies, 11(2), 9-18.

Sunarsih, N., \& Helmiatin. (2017). Influence of Organizational Climate, Motivation, and Job 


\section{International Journal of Business Management and Economic Review}

Vol. 4, No. 04; 2021

ISSN: 2581-4664

Satisfaction on Employee Performance. Review of Integrative Business and Economics Research, 6(1), 262-276.

Sunyoto, D. (2012). Manajemen Sumber Daya Manusia: dilengkapi dengan Budaya Organisasi, Pengembangan Organisasi, Outsourcing. Yogyakarta: Caps.

Swalhi, A., Zgoulli, S., \& Hofaidhllaoui, M. (2017). The influence of organizational justice on job performance: The mediating effect of affective commitment. Journal of Management Development, 36(4), 542-559. https://doi.org/10.1108/JMD-11-2015-0162

Syahrum, A., Brahmasari, I. A., \& Nugroho, R. (2016). Effect of Competence, Organizational Culture and Climate of Organization to the Organizational Commitment, Job Satisfaction and the Performance of Employees in the Scope of Makassar City Government. International Journal of Business and Management Invention, 5(4), 52-64.

Wahyuni, S., Idris, H. A., \& Noor, M. (2013). Faktor-Faktor Yang Berpengaruh Terhadap Kinerja Pegawai pada Dinas Pertanian dan Peternakan Kabupaten Kutai Timur. EJournal Administrative Reform, 1(2), 444-457.

Wiwiek, \& Sondakh, O. (2015). Pengaruh Keadilan Organisasi pada Motivasi Kerja Karyawan dan Komitmen Organisasional. Jurnal Siasat Bisnis, 19(1), 69-77. https://doi.org/https://doi.org/10.20885/jsb.vol19.iss1.art6

Yantu, I. (2018). Organizational Climate For Work Motivation Stimulation In Regional Financial Agency. Jurnal Aplikasi Manajemen, 16(2), 303-335. https://doi.org/http://dx.doi.org/ 10.21776/ub.jam.2018. 016.02.16

Zapata-Phelan, C. P., Colquitt, J. A., Scott, B. A., \& Livingston, B. A. (2009). Procedural justice, interactional justice, and task performance: The mediating role of intrinsic motivation. Organizational Behavior and Human Decision Processes, 108(1), 93-105. 